論 文

カルマンフィルタを適用した聴性脳幹反応波形の特徵抽出とモデル化

\author{
井川 信子 ${ }^{1}$, 谷萩 隆嗣 ${ }^{2}$ \\ 1 流通経済大学法学部 \\ 2 千葉大学大学院自然科学研究科
}

\title{
A Method for Modeling and Feature Extraction of Auditory Brainstem Responses Using Kalman Filter
}

\author{
Nobuko Ikawa ${ }^{1}$ and Takashi Yahagi ${ }^{2}$ \\ ${ }^{1}$ Faculty of Law, Ryutsu Keizai University, Ryugasaki 301-8555, Japan \\ ${ }^{2}$ Graduate School of Science and Technology, Chiba University, Chiba 263-8522, Japan \\ E·mail:ikawa@rku.ac.jp
}

\begin{abstract}
In this paper, we apply the minimum variance estimation algorithm using a Kalman filter to the waveform data of auditory brainstem response (ABR). The model parameters that extract the feature are obtained effectively by our proposed method. The ABR is usually analyzed by the batch processing through addition for a few minutes because of its slight potential. We will expand the possibility of measuring it online by minimizing the model error based on a Kalman filter. We especially discuss the type and the degree of the estimated transfer function. We use the ABR waves obtained by averaging (traditional method) less than 2000 times and estimate its transfer function to extract the feature using a Kalman filter. The result of our method showed a higher correlation than traditional method of averaging to the ABR signal. If it is possible to apply this method to clinical cases, we can expect much reduction of the addition of signals which contributes to speed-up the monitor diagnoses in the emergency medical care and the operation, etc.
\end{abstract}

Keywords: auditory brainstem response, linear model, AIC, Kalman filter

\section{1.はじめに}

\section{1 聴性脳幹反応と臨床応用}

聴性脳幹反念 (ABR : auditory brainstem response) は 両耳あるいは片耳から音刺激を与えてから $10 \mathrm{~ms}$ 以内に 潜時を持つ聴性誘発脳波の短潜時成分で，反忘の振幅は1 $\mu \mathrm{V}$ 以下の低電位，第 I 波加第 $\mathrm{II}$ 波で構成される多相性 の陽性波である（図 1) [1]。各波の形成は脎幹における聴 覚系神経路の特定部位に由来し, 生理学および解剖学にお いてその起源がほぼ特定されているため[2], 脳幹内病変の 部位, 病変の聴覚系神経路に与える障害の程度の診断, 意 Journal of Signal Processing, Vol. 8, No. 4, July 2004
識障害や脳死判定の補助検査などの臨床応用がある[1]。 また，耳鼻科においては他覚的聴覚検查として，詐聴の 診断や機能性難聴の診断などに利用されている[3]。他覚的 聴覚検查とは, 新生児や乳幼児を含め, 被験者が自分で“聞 こえるか聞こえないがについて正確な意思表示ができな い場合や，全身麻酔下の被験者や重症な身体障害により意 思表示が困難な被験者, あるいは犯罪捜查などで “聞こえ ているのに聞こえないふりをする”いわゆる “詐称難聴” の可能性のある被験者などに対して実施される検查である。 一方, 自覚的聴覚検查とは, 複数の周波数による検查音の

“聞こえ”の状態に対する被験者自身の反忘に基づく検查 である。特に, 新生児の聴覚スクリーニング用装置として, 
聴覚検查に有効な第 V波成分のみに特化して自動的に診断 判定する自動聴性脳幹反応 (AABR : automated auditory brainstem response）検査装置が，近年，B.S. Hermann ら[4],[5]によって設計・開発され，製品化されている[6]。 この装置は, 従来のABRに比べて平均 5 分の 1 の速さで検 查が実施される[6]ばかりか，高度な検查技術および判読技 術を要しないので, 従来のABRに比べてより大量, 短期間 での検査実施を可能にしている。

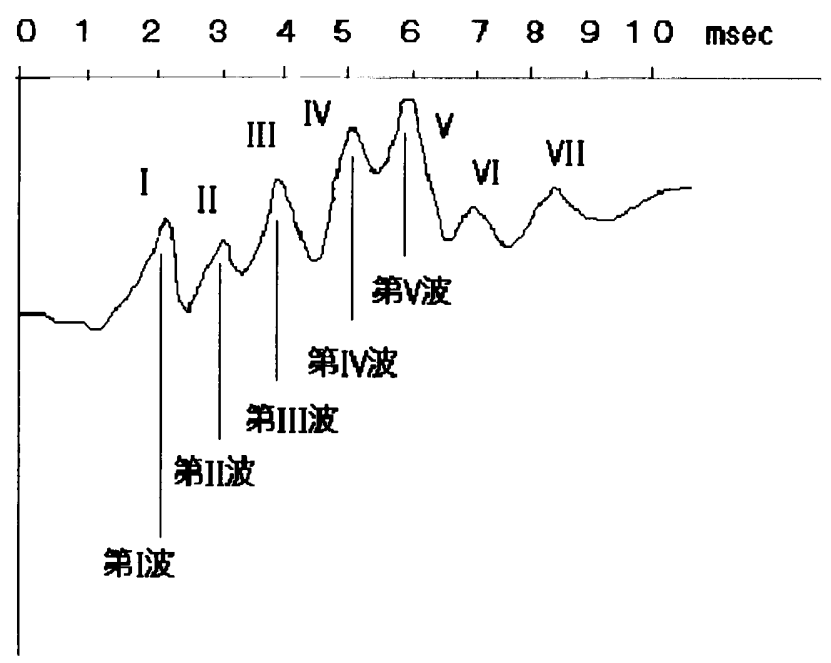

図1 7つのピークを持つABR波形例（ヒト）(文献[1])

Fig.1 Sample of a waveform of ABR with 7 peaks (after Reference[1])

\subsection{ABRと加算}

$\mathrm{ABR}$ な゙の誘発反応は，自発脳波などの背景雑音に埋ま っている微小な反忘 (通常脑波の1/5〜1/100の振幅[1], [3]) のため, 検出する際に一般に 2000 回程度の加算処理を実施 する。ここで加算処理とは，雑音に埋もれた信号を明瞭に するための手法で，何回も刺激を与え，それぞれの刺激に 対する波形を加算して明膫な波形を得るという方法である。 加算後に加算回数で割ることによって平均化を行う。信号 (反応)が各刺激に対して同一の潜時とパターンで出現し, しかも背景の電位変動がランダムであれば $N$ 回の加算平 均によって反応振幅は変化しないが雑音の振幅は $1 / \sqrt{N}$ と小さくなる[1], [3], [7]。この原理を利用して, ABR波 形も検出されている。このようにABRはオンライン検査で はないので, 測定に要する時間は短くはなく（平均 30 分 程度)，その間患者にストレスを与え続けている。またこれ が緊急時の迅速な計測を妨げる要因の 1 つにもなっている。

自動聴性脳幹反応(AABR)による新生児聴覚スクリーニ ングの場合, 従来のABRに比べて検査時間が短縮されたと はいえ,この加算に要する時間の部分は軽減されていない。 また, AABR検査の結果” refer (要再検査)”となった場
合は,やはり従来のABRによる検査を新生児に対して用い なければならないのが現状である。

そこで，本論文では，音刺激クリックが誘発する聴覚性 誘発電位の波形デ一タから, カルマンフィルタを適用した 最小分散推定アルゴリズムを用いて，波形パラメータを推 定するモデル式を導入することを試みている。モデル式の 同定が可能となれば, AABR と同様, 他覚的聴覚検查のた めの自動化をめざす数式化の方向性を，一般被験者に対し て実施することも可能になると考えられる。特に, ” 平均加 算”によるストレスをできる限り減ずるための手段が必要 である。本提案の手法であるカルマンフィルタを適用した 最小分散推定法を用いることにより，モデル式が同定され れば, ABR波形のオンライン計測を可能とする, パラメー タが求められることとなる。

\section{3 各章の構成}

以下では, まず, カルマンフィルタを適用した最小分散 推定アルゴリズムについて論じ，モデル式を決定する。次 に, あらかじめ計測してあるABRデータを実験データとし てこのモデル式にあてはめ, 最適解を求め, ABR実験デ一 夕に対するパラメータを推定する。そして，その結果につ いて考察する。

本論文の具体的な章構成は，以下のとおりである。すな わち，2 章では，本論文の基礎となるカルマンフィルタを 適用した最小分散推定アルゴリズムに基づくモデル式につ いて論じ，これを決定する。3章では，あらかじめ計測し てあるABRデータを 2 章で決定したモデル式にあてはめ て, 最適解を求める方法について説明し, 計算結果を述べ る。4章では，カルマンフィルタによるモデルを，より少 ない加算回数の観測波形に適用し，俰数の特徽を抽出する。 また，雑音成分の特性を抽出し，これを利用して，少ない 加算回数の信号成分を推定する手法について論じ，モデル の妥当性を評価し,パラメータ推定を確定する。5章では, まとめおよび今後の方針ていて述べる。

\section{2. カルマンフィルタを適用した最小分散 推定によるパラメータ推定}

一般的に広く知られている[7]ように, 脳波や笳電などの 不規則な生体信号は，確率過程，たとえばガウス過程など で数学的モデル化が行われる。ABRは特に, 臨床診断指標 として潜時という時間的構造あるいは生成規則の解析が重 要であると考えられるため, 時系列を生成するモデルを用 いるのが妥当であると考える。今回は，その時系列生成モ デルのパラメータ推定の方法を適用することにする[8]。そ の推定法について簡単に説明する。

Journal of Signal Processing, Vol. 8, No. 4, July 2004 


\section{1 伝達関数の推定 [8]}

\subsection{1 カルマンフィルタを適用した最小分散推定法 によるパラメータ推定}

$\mathrm{ABR}$ は誘発電位である。すなわち, 外部入力をもつイン パルス応答列であるから，入出力関係式を次のような形の 差分方程式

$$
y(t)=-\sum_{i=1}^{n} a_{i} y(t-i)+\sum_{i=1}^{n} b_{i} u(t-i)+v(t) \quad t=0,1, \cdots
$$

で表されるモデル式を，ABRにおけるパラメータ推定式と する。ただし， $y(t), u(t), v(t)$ はそれぞれ時刻 $t$ における出 力，入力およひ雑音成分を表している。 $u$ と $v$ とは互いに 独立であり, $v$ は平均值 0 , 分散 $\sigma_{v}{ }^{2}$ (未知)の定常な白色雑 音であるとする。一般に観測雑音は脳内の背景雑音やセン サ（電極）の観測雑音などからなる不規則雑音であるが, 必要に応じて雑音モデル[8]を導入すれば $v(t)$ を白色雑音 としてモデル化することができる。

式(1)で入出力信号は観測可能であるので, カルマンフィ ルタを適用した最小分散推定による逐次推定アルゴリズム を適用してパラメータ $a_{i}, b_{i}(i=1,2, \cdots, n)$ を推定する。 すなわち，未知パラメータを並べたパラメータベクトル $\theta=\left[a^{T}, b^{T}\right]^{T}$ に対し, 時刻 $t$ までの入出力デー夕を観測し て得られる $\underline{\theta}$ の推定值を $\hat{\theta}(t)$ と表し

$$
\begin{aligned}
& \underline{\hat{\theta}}(t+1)=\underline{\hat{\theta}}(t)+\underline{k}(t+1)\left[y(t+1)-\underline{z}^{T}(t+1) \underline{\hat{\theta}}(t)\right] \\
& \underline{k}(t+1)=\frac{\underline{R}(t) \underline{z}(t+1)}{\hat{\sigma}_{v}^{2}(t+1)+\underline{z}^{T}(t+1) \underline{R}(t) \underline{z}(t+1)} \\
& \underline{R}(t+1)=\left[\underline{I}-\underline{k}(t+1) \underline{z}^{T}(t+1)\right] \underline{R}(t) \\
& \hat{v}(t+1)=y(t+1)-\underline{z}^{T}(t+1) \underline{\hat{\theta}}(t) \\
& \hat{\sigma}_{v}{ }^{2}(t+1)=\frac{1}{t+1} \sum_{i=0}^{t} \hat{v}^{2}(i+1)
\end{aligned}
$$

を用いて推定する。ただし $T$ は転置を表しており， $\underline{z}$ は 次式で与えられる。

$$
\underline{z}(t+1)=\left(\begin{array}{l}
-y(t) \\
\vdots \\
-y(t-n+1) \\
u(t) \\
\vdots \\
u(t-n+1)
\end{array}\right)
$$

Journal of Signal Processing, Vol. 8, No. 4, July 2004

\section{1 .2 次数の決定}

次に, 最適な次数 $n$ を評価するために赤池のAIC[8]を用 いる。AICは以下の計算式で計算する。

$$
A I C(n)=N * \ln \hat{\sigma}_{v}{ }^{2}+4 n+N(1+\ln 2 \pi)
$$

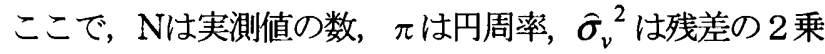
和, $2 n$ はパラメータの数を表す。AICの值が最も小さい $n$ を最適次数と設定する。

\subsection{3 伝達関数の周波数特性[9]}

式(1)より伝達関数は

$$
H(z)=\frac{b_{1} z^{-1}+\cdots \cdots+b_{n} z^{-n}}{1+a_{1} z^{-1}+\cdots+a_{n} z^{-n}}
$$

と表されるので, $z=e^{j \omega}(0 \leq \omega \leq \pi)$ と置けば

$$
H\left(e^{j \omega}\right)=\frac{C(\omega)-j D(\omega)}{A(\omega)-j B(\omega)}=\left|H\left(e^{j \omega}\right)\right| e^{j \Phi(\omega)}
$$

ただし

$$
\begin{aligned}
& A(\omega)=1+a_{1} \cos \omega+a_{2} \cos 2 \omega+\cdots+a_{n} \cos n \omega \\
& B(\omega)=a_{1} \sin \omega+a_{2} \sin 2 \omega+\cdots \cdots \cdots+a_{n} \sin n \omega \\
& C(\omega)=b_{1} \cos \omega+b_{2} \cos 2 \omega+\cdots \cdots \cdots \cdots+b_{n} \cos n \omega \\
& D(\omega)=b_{1} \sin \omega+b_{2} \sin 2 \omega+\cdots \cdots \cdots+b_{n} \sin n \omega
\end{aligned}
$$

であり，周波数特性を次式で求める。式(10)は振幅特性， 式(11)は位相特性を表す。

$$
\begin{aligned}
& \left|H\left(e^{j \omega}\right)\right|=\sqrt{\frac{C^{2}(\omega)+D^{2}(\omega)}{A^{2}(\omega)+B^{2}(\omega)}} \\
& \Phi(\omega)=\tan ^{-1}\left(\frac{B(\omega) C(\omega)-A(\omega) D(\omega)}{A(\omega) C(\omega)+B(\omega) D(\omega)}\right)
\end{aligned}
$$

\section{ABRのパラメータ推定}

前述の推定法を用いてABR計測条件にあったモデル式 の形を決定する。まず，実験に用いるABRデータについて 述べ，このデータにモデル式を適用する妥当性を検証する ために測定したABR波形の雑音特性を調べる。そのうえで $\mathrm{ABR}$ 波形伝達関数の保数の最適な推定值を求める。本章で は，この手順および結果について述べる。

\section{$3.1 \mathrm{ABR}$ 波形導出と特性}

$\mathrm{ABR}$ は，与えられる刺激音の種類によっても出力特性が 異なるが，この点に関しては我々がこれまでに実施した方 法を前提にする[10]。すなわち，刺激音は立ち上がりが鋭 
く，広い周波数成分を含むため最も多く用いられるクリッ ク（刺激幅は可能な限り小さいもの，使用した装置での最 小值は0.1msec）とする。

また, 誘発電位の解析は, 繰り返し実験による多数のデ 一夕を刺激時点に同期させた加算平均により，背景脳波か ら選択的に誘発波形を取り出すのが，従来の方法である。 ABRの加算回数は従来500～2000回の範用で設定される。 健常者で反応が明確な場合は，ほぼ500回程度で波形を得 ることができる。逆に，脳死患者の判定補助に用いられる 場合では, たとえば”2500回加算平均を害施しても反応が 得られない”ということで, ”無反応” の判定とするなどで ある。新生児聴覚スクリーニングに用いられる装置 (natus-ALGO-2e) の場合は, 最大15000回まで加算する ことができる[6]。これは，検査を受ける新生児へのストレ スを軽减する目的で, 比較的低い音圧で検查を実施するの で, より多くの加算回数が必要となるためである。

刺激音圧は最も影響の大きい入力因子[10] であるため, 検査の目的によって異なる。聴神経腫瘍, 多発性硬化症の 診断など神経学的診断には80dBnHL程度閥值上の十分大 きな音圧を用いる。ここでnHLとは, Normal Hearing Level のことで, 健常人の平均最小可聴值を $0 \mathrm{~dB}$ として刺 激音圧を聴覚レベルで表したものである。また，伝音難聴

（鼓膜穿孔）や感音難聴（内耳性）など耳鼻科における聴 力推定検査では, $80 \mathrm{dBnHL} \sim 30 \mathrm{dBnHL}$ 程度の範囲の音圧 で検出する。音圧が高いほど波形は計測しやすいが, $90 \mathrm{dBnHL}$ 程度が検査上の上限値と考えられる。新生児聴 覚スクリーニングに用いられる装置 (natus-ALGO-2e) の 場合では，35dBnHLに刺激音圧を固定している[6]。

以上のように診断に適用する場合, 各反心波形のピーク 潜時やピーク間潜時といった時間的構造の特徵に注目する 場合が比較的多くみうけられるので, 先に述べた時系列生 成モデルの推定法によるパラメータ推定の方法を適用する ことが妥当であると考える。

\subsection{ABR実験データと雑音の性質}

$\mathrm{ABR}$ 実験環境と，最適音刺激について述べ，この条件下 で検出したABRサンプリングデータを実験データとして 使用する。

\subsection{1 刺激条件}

$\mathrm{ABR}$ の測定は, 18-22歳の聴覚健常男性30名を被験者と して行った。音刺激のパラメータを次のように設定した。 刺激音圧は30から $90 \mathrm{~dB}$ nHLまで10dB nHL毎可変にした。 刺激幅は，潜時に影響を与える実用範用の $0.1,0.3,0.5,1.0$ $\mathrm{ms}$ の 4 種類にした。刺激頻度は, $80 \mathrm{~Hz}$ 以下で第 $\mathrm{V}$ 波の潜 時が顕著に変わることが知られているため, 20,40,60,80 $\mathrm{Hz}$ の種類とした。ABR信号波形検出の加算回数は2000 回とし，導出電極を置いた頭頂（vertex, $\mathrm{Cz}$ ）と基淮電極 338
を置いた耳架（A1,A2）より脳波用血電極 $\mathrm{Ag}-\mathrm{AgCl}$ にて双 極導出, 電極ペーストや皮膚の前処理により接触抵抗は $5 \mathrm{k}$ S以下とし，接地電極を前額(Frontal，Fpz)に置き，両耳 刺激とした。両耳間は電気的に短絡して等電位とした。加 算および記録には，日本光電社製Neuropack Four miniを 用いた。また，帯域フィルタの通過帯域を $100 \mathrm{~Hz} \sim 1500$ $\mathrm{Hz}$ に設定した。本論文のモデル式に適用したABRデータ は，このうちの同一最適束激に対する計測值ピーク潜時検 出の誤差限界内（ピーク潜時が検出されている）の顕著な データである。加算は出力波形を時間的にサンプリングし てディジタル值に変換した数值を使って行う。この時間的 サンプリングはサンプリング時間を $10 \mathrm{msec}$, サンプリング 点を512点とした。したがってサンプリング間隔は0.019 msec (10 msec/512点) である。また少加算回数における 出力波形のサンプリング值は, 計測時にファイルに出力す るように計測プログラムに設定をして検出した。最適刺激 条件は以下のとおりである：

$\begin{array}{ll}\text { 刺激音 : } & \text { クリック } \\ \text { 刺激音圧 : } & 80 \mathrm{dBnHL} \\ \text { 刺激幅 : } & 0.1 \mathrm{msec} \\ \text { 刺激頻度 : } & 40 \mathrm{~Hz}\end{array}$

\subsection{2 加算回数2000回のABR波形}

一般に臨床的応用において妥当であると考えられる加算 回数2000回のABR波形を信号波形と考えることにする。し

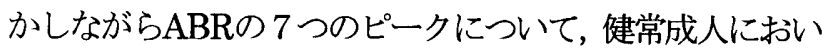
て常に同様の出力を得るとは限らない。たとえば，もっと も顕著な第IV波とV波に対して, 文献[3] (p.49) では分離, 融合について健常成人における“IV-V波バリエーション” を 3 つの型に分類している。すなわち聴力正常成人 613 人 に対して検査音をクリック，80dBnHLによる結果として 報告している。1型は，IV波とV波が分離しかつV波の振 幅がIV波の振幅より大きいもの（出現率53\%)，2型は，IV 波とV波が分離しかつV波の振幅がIV波の振幅より小さい もの（出現率 $27 \%$ )，3型は，IV波とV波が複合波を形成す るもの（出現率 $20 \% ）$ と定義している。3型についてはIV 波とV波が完全に融合しているもののほかにIV波がV波の 肩に乗るもの $(3-1), \mathrm{V}$ 波がIV波の肩に乗るもの $(3-2)$ も含めている。実際, この 4 つ型による分類に基づいて, 我々の実験によるABR観測波形から図 2 (a)〜 (d)に示す 4 つの観測波形を，モデル式を求めるための信号波形として 選んでいる。

Journal of Signal Processing, Vol. 8, No. 4, July 2004 


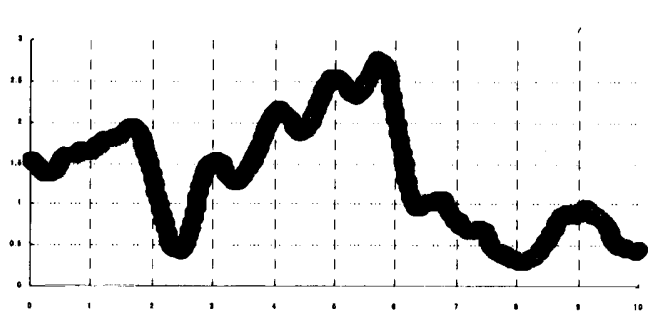

(a)ABR场波形2000回加筆: 1 犁

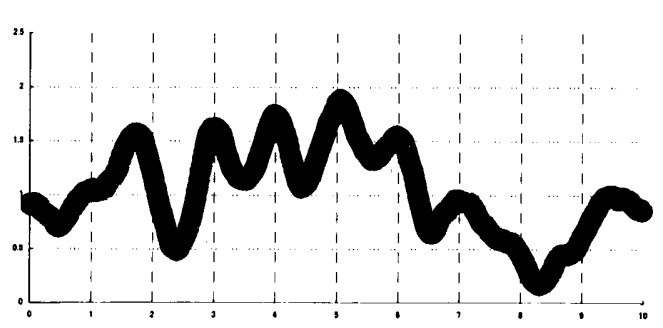

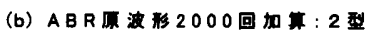

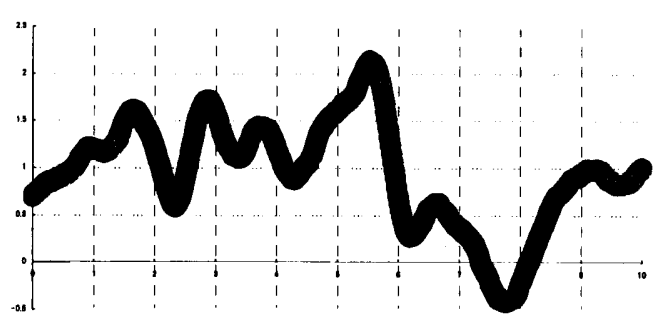

(c) ABR原波形 2000 回加策: 3-1型

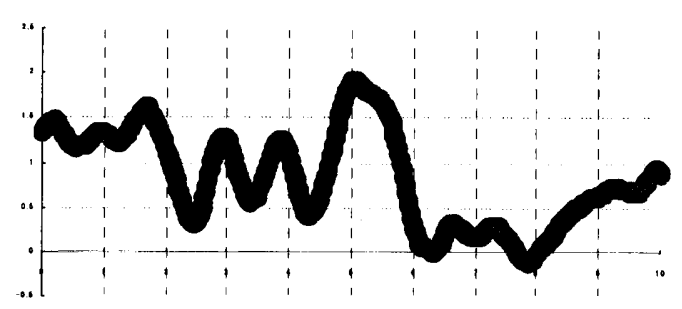

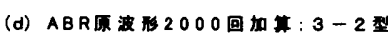

図2 2000回加算におけるABR原波形サンプル值 (1型(a), 2型(b), 3-1型(c), 3-2型(d))

Fig.2 Experimental data of the ABR of types 1(a), 2(b), 3-1(c), 3-2(d) for 2000 sweep times

\subsection{3 加算回数とABR実験钼測波形の雑音成分}

次に，各加算回数で検出したABRデー夕を用いてABR 実験観測波形の雑音成分について分析する。つまり平均加 算の仕組は図 3 のように, クリック刺激によって得られた 10 ミリ秒内のABR観測波形の各サンプル值で加算平均を 求めている。従って，たとえば10回加算とは，上記の刺激 一観測を10回繰り返して得られた加算波形の平均值出力 を意味している。4つの型のうち 3-1型ABR波形を例とし てそれぞれ，加算回数 $1,2,4,10,20,30,40,100,200,300,1000$, 1500,2000 で検出したABR観測波形を用いて加算回数と雑 音成分について調べる。まず実際に得られた各加算による ABR 観測波形を図 4の(a) (m) に示寸。図に示すように, Journal of Signal Processing, Vol. 8, No. 4, July 2004
加算を繰り返すことによって次第に雑音成分が除去され， 信号の振幅となるため，振幅が減少して，波形形状がわか りにくくなる。そこで加算回数 1 ～100回に対して，加算回 数200〜2000の波形は振幅值約5.6倍で表示している。この 観測値の場合, 第 $\mathrm{V}$ 波は加算200回あたりから成長し, 加 算1000回以降でほほ影著となっている。また，第 $\mathrm{V}$ 波の潜 時は5.53，波形パターンは第IV波，V波融合タイプ (3-1 型 : 疾患ではない[1]）である。

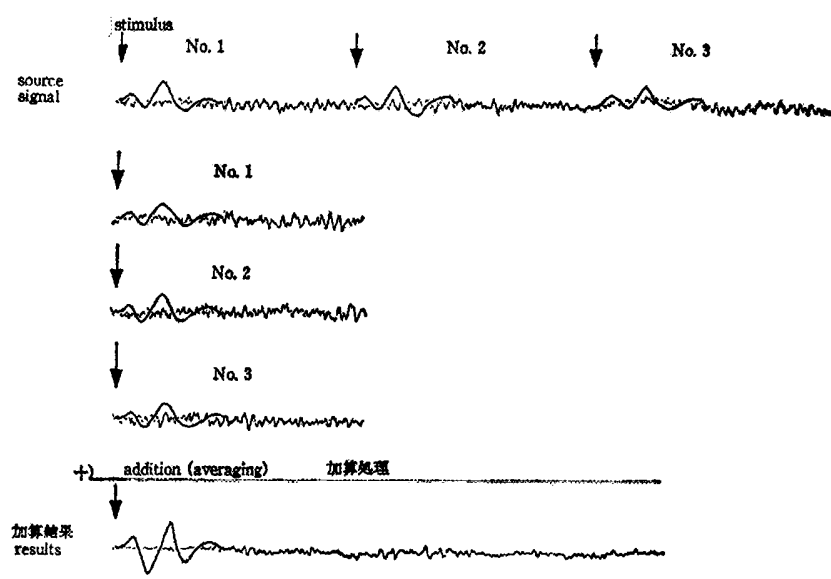

図 3 加算処理の原理模式図（文献[1]p. 100, 図7-10)

Fig.3 Image of averaging for the ABR source signal ([1] p.100, Figs.7-10)

ここで雑音成分を定量的に分析する。まず，この加算值 の集合を $K=\{k(i), 1 \leqq i \leqq 13\}, \mathrm{AB}$ R波形(のサンプル值) を $x_{k(i)}(t), 0 \leqq \mathrm{t} \leqq 10$ (ミリ秒), $\mathrm{ABR}$ 信号成分を $S_{A B R}(t), k(i)$ 回目の雑音成分を $v_{k(i)}(t)$ とおくと, $x_{k(i)}(t)=S_{A B R}(t)+v_{k(i)}(t)$ となる。そこで $k(13)=2000$ 回の波形を基淮波形として各加算回における雑音を算出し て, その分散を求める。すなわち, $x_{2000}(t)=S_{A B R}(t)$ と して $x_{2000}(t)-x_{k(i)}(t)=-v_{k(i)}(t)$ を計算して図に表した ものが図 5 である。この図表から雑音の分散は加算回数の 增大にともなって減少し，次第に0（ゼロ）に近づくこと がわかる。

さらに，図4で示した加算2000回とより低い加算の観測 波形の相関度を計測するために， $x_{2000}(t)$ と $x_{k(i)}(t)$ との 相関係数を計算して, 図示したものが図6である。200回 では0.6，1000回で0.96という相関係数から，200回以上か ら波形の出現率が上がり, 1000回程度でほぼ2000回の波形 に近い波形を得られているとみることができる。

特に図5の結果から，実験に採用するABR波形データの 雑音成分の分散は加算回数の增大とともにゼ口に近づくこ とが示された。他の型におけるABR実験観測波形に対して も同様の結果を得ている。

図 5 に加えてさらに, 図7では加算10回と2000回につい ての雑音のパワースペクトル (FFT) の結果を示寸。これ 
らからさらに, 雑音のランダム性をも仮定してほぼ支障が ないと考えて良いということができる。

\section{3 推定モデル式の条件}

このように，雑音の特性からモデルの適用の妥当性をほ ぼ保証したといえる。一方，各回の ABR 計測において入 力はインパルスであるとみなせるので

$$
u(t)= \begin{cases}1 & t=0 \\ 0 & t=1,2,3, \cdots\end{cases}
$$

であるとする。また，最初はパラメータの值がまったく未 知であることを考慮して式(2),(3),(4)の初期值を $\gamma=1.0 \times 10^{5}, \underline{\hat{\theta}}(0)=0, \underline{R}(0)=\gamma \underline{I} \quad$ とする。 定義式加

$$
\hat{\theta}(t)=\left(\begin{array}{c}
-a_{1}(t) \\
-a_{2}(t) \\
\cdots \\
-a_{n}(t) \\
b_{1}(t) \\
b_{2}(t) \\
\cdots \\
b_{n}(t)
\end{array}\right)
$$

であるので, $\underline{\hat{\theta}}(t)$ の収束值が伝達関数の係数となる。この ときの伝達関数は式(8)で表されるが, 伝達関数の分母と分 子に共通根があれば，それを消去したものを伝達関数とし て採用することになる。

\section{4 次数の決定}

\subsection{1 $\mathrm{AIC}(n)$ の最小值}

3.2.3で述べた実験デ一タにおける雑音成分の特性から, ほほ2000回をABR信号成分とみなしてよいので, 実験モデ ルの最適次数 $n$ の推定はまず加算回数 2000 回の場合につ いて3.3で仮定した実験モデル式に対して, $\operatorname{AIC}(n)$ を式(7) によって計算すれば良いことになる。まず，加算2000回 $\mathrm{ABR}$ のつの型（図2）についてAIC $(n)$ の最小值を求める と, 表 1 の結果となった。たとえば, 3-1型を例に図8に示 す。 $\operatorname{AIC}(n)$ は, $n<18$ で単調に減少し, $n=18$ で最小值と なる。その後 $18<n<60$ で単調に増加している。しかし， ここで単にAIC $(n)$ の最小值を最適次数之考えて良いかに ついて次節で評価する。

\section{4 .2 加算回数 2000 回 ABR 波形の次数の評価}

AIC を用いてカルマンフィルタを適用した最小分散推 定法アルゴリズムによるモデルのパラメータ次数を求めた が，この結果の妥当性について検証する必要がある。つま
り，AICで得られた最小值は，雑音の影響などでモデルの 次数を実際以上に高く推定してしまい，対象の本質的な部 分を反映させるのではなく雑音的な部分を反映させる傾向 が疑えるからである。そこで, AIC の最小值を AICmin としたとき，

$$
|A I C(n)-A I C \min | \leqq \delta \quad \delta: \text { 適当な正数 }
$$

を満たす最小の $n$ を, ABR 信号波形モデルの次数として採 用することにする。ここで， $\delta$ は， $\delta=M \times \varepsilon ，$ $M=\max |(A I C \max -A I C \min )|, \quad \varepsilon$ : 絶対值の最大値 による正規化をしたときの最大許容值とする。

再び，図9は4つの型（図2）についてのAIC值（は縦軸， 横軸は次数 $n$ ) を表示している。図中の小さい矢印は, 各 型におけるAICの最小值を表す。また，縦に下向きに表示 した矢印は，上記の方法で各型について評価した結果得ら れた 4 つの型の平均, 寸なわちABR波形信号モデルの最適 次数を表している。この結果から $n=8$ を得る。

\subsection{ABR 伝達関数の決定}

$\mathrm{ABR}$ 伝達関数係数は, カルマンフィルタの式(4)における 行列 $\underline{R}(t+1)$ の対角成分であるモデル式の係数 $a_{i}, b_{i}$ $(i=1,2, \cdots, n)$ の適当な残差に対する, その収束值加求 める。ABR加算2000回3-1型信号波形のAIC最適次数にお ける伝達関数係数の収束例を図10に示す。図10(a)は倸数系 列 $a_{i}$, 図10(b)は係数系列 $b_{i}$ を示す。図をみると， $a_{1}$ の值 の絶対值が最も大きい。これは，予測值出力には直前の観 測出力が最も影響するという結果を示している。

\subsubsection{ABR（加算回数 2000 回）の場合の伝達関数の 係数}

図10ではAIC最適次数で推定した伝達関数の保数を示し た。実際,この次数の妥当性について再度確認する意味で, 次数評価で得られた最適次数 $n=8$ とAICの最小值 $n=18$ 場 合について, ABR波2000回における4つの型のABRに対して, 両者における伝達関数の係数の収束值を求めて比較する。 すなわち, 図11(a) はAICの最小值 $(n=18)$, 図11 (b) は最適 值 $(n=8)$ の場合における $a_{i}(i=1,2, \cdots, n)$ の収束値をそ れぞれ示している。この結果から，どちらもほぼ同様の係 数㒋向を得ているので, 3.4 .2 におけるより低い次数の最適 次数の評価脮当であるということができる。

\subsubsection{ABR 波形予測結果（加算回数 2000 回）}

伝達関数倸数の最適值を用いて, 2000 回加算時の 4 つ の型における $\mathrm{ABR}$ 計算予測值を算出して, $\mathrm{ABR}$ 波形観測 值と比較したものを図 12 に示寸。(a) 〜 (d) はそれぞれ タイプ1,2,3-1,3-2 の結果である。各 (a)～（d）において 一番下の図が $\mathrm{ABR}$ 観測值（サンプリング值）を，中段が カルマンフィルタを用いた $\mathrm{ABR}$ 計算予測值，上段は予測 誤差系列を表す。上段図中基線の上下に示された横線は,

Journal of Signal Processing, Vol. 8, No. 4, July 2004 

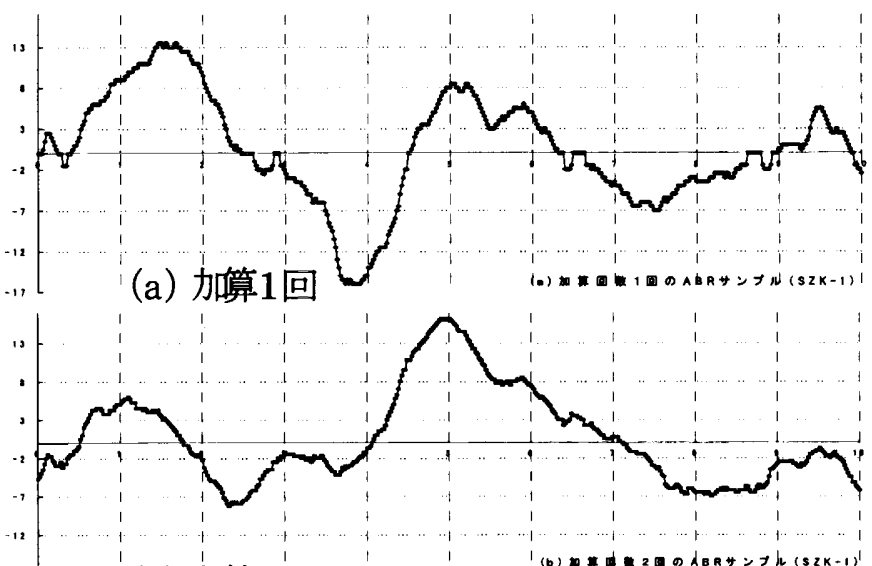

(b) 加算2回

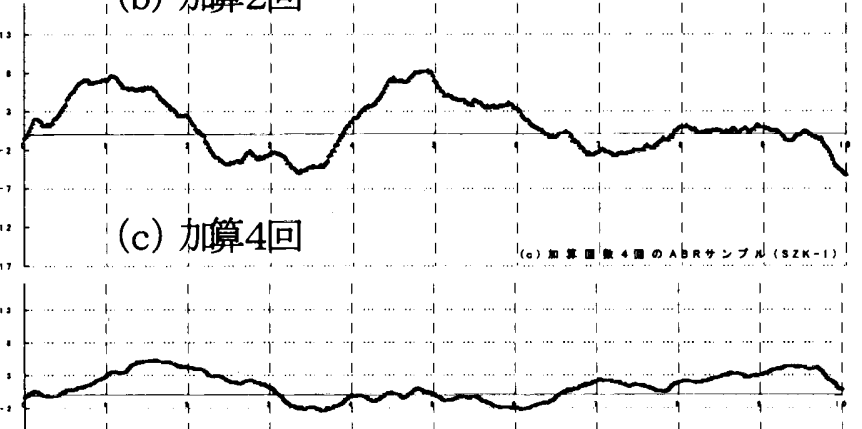

(d) 加算1 0 回

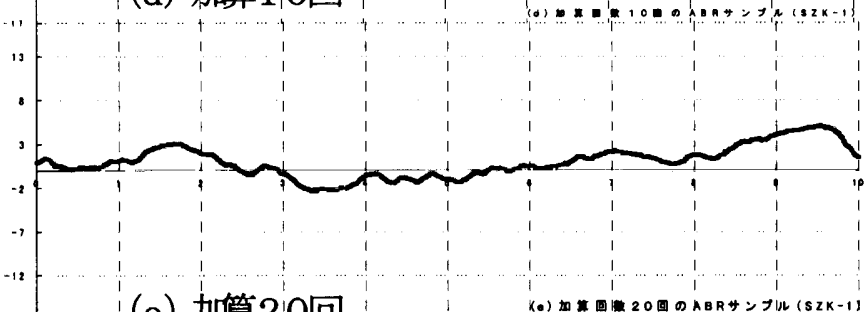

(e) 加算20回

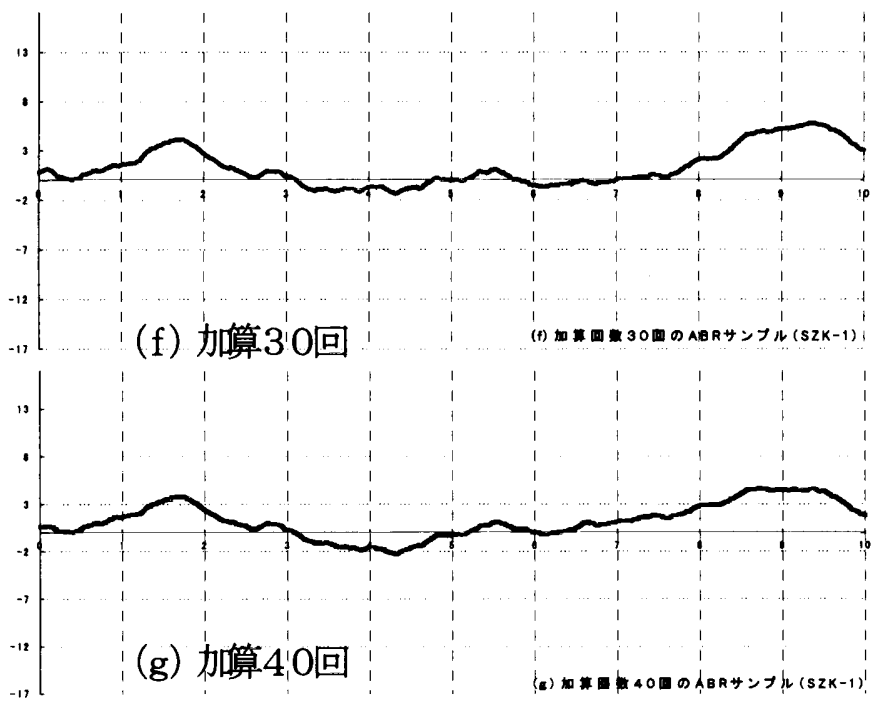

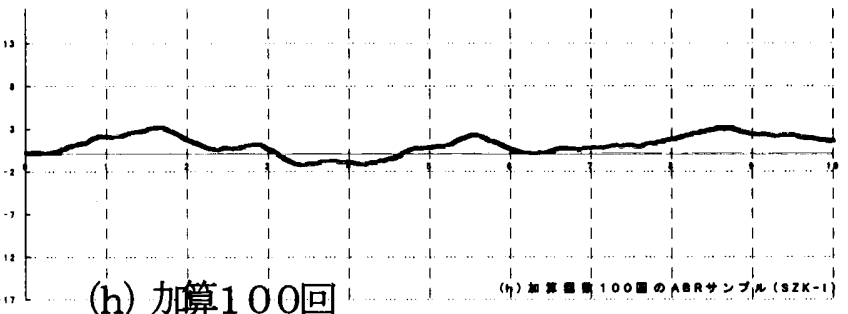

上降，尉副》蟀約 5 .7倍さする 㵊大 $17=8)$

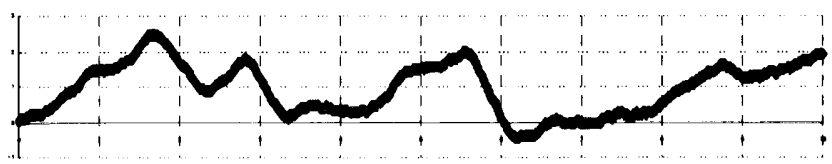

(i) 加算200回

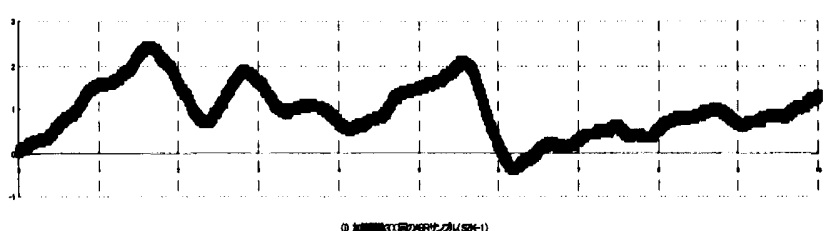

（j）加算300回

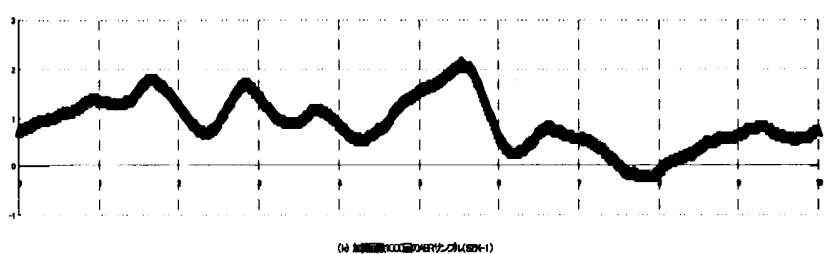

(k) 加算1 000回

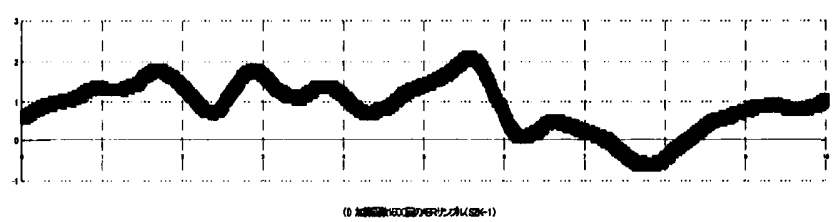

(1) 加算 1500 回

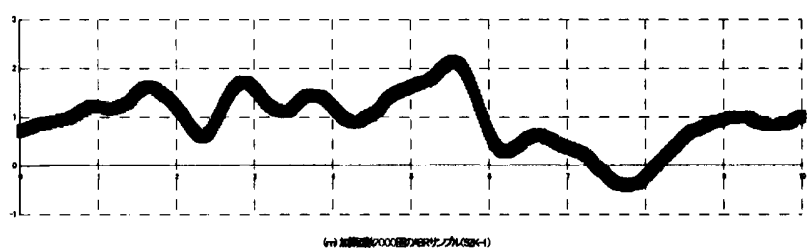

(m) 加算2000回

図4 各加算回数における $\mathrm{ABR}$ 原波形サンプル值

Fig.4 Experimental data of the ABR for various sweep times 


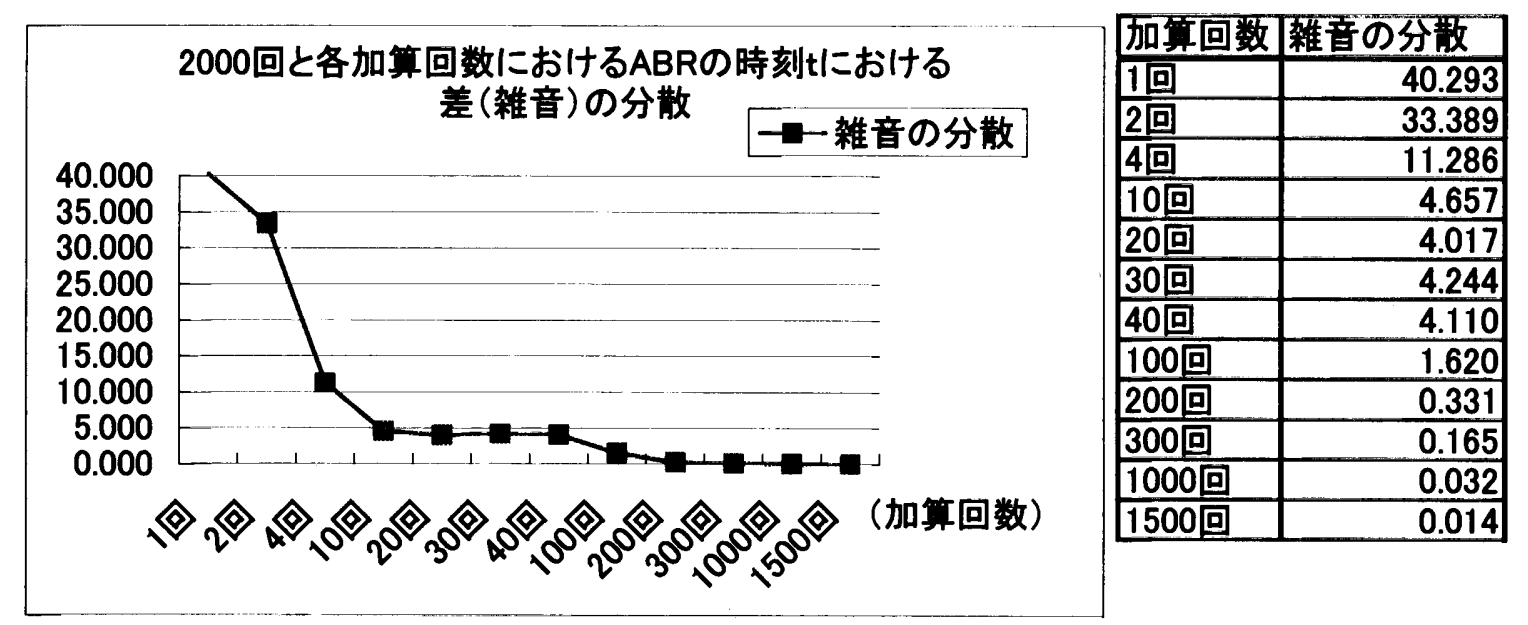

図 5 各加算回数における雑音の分散

Fig.5 Variance of noise for each sweep time of the ABR source signal

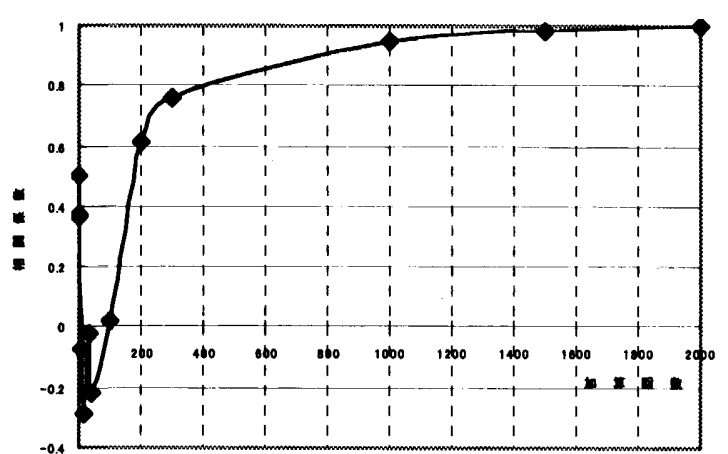

図6 各加算回数におけるABR波形と2000回加算におけ るABR波形との相関（横軸が各加算回数を表し，縌 軸が各加算回数におうけるABR波形と 2000 回加算に おけるABR波形との相関係数)

Fig.6 Relationship between the correlation value of each ABR wave and its sweep times

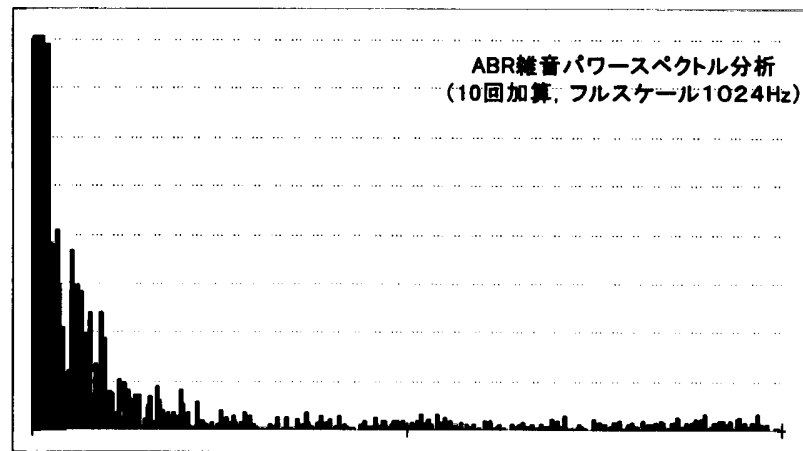

ABR萧音パワースペクトル分析 (1500回加年, フルスケール1024 Hz)

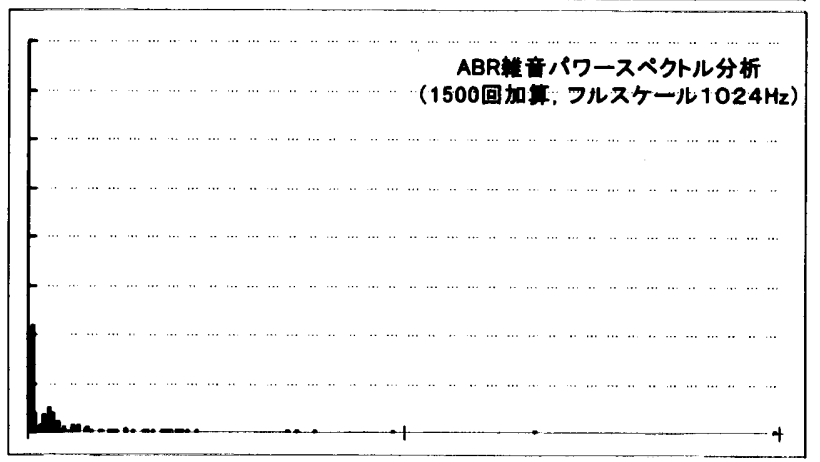

図 7 FFTによる加算10回と加算1500回の雑音成分の パワースペクトル

Fig.7 Power spectra of the noises of 10 and 1500 sweep time data 
表 1 実験モデルを加算回数 2000 回のABRに適用した場 合の AIC の最小值と次数の関係

Table 1 Relationship between minimum AIC value and degree when experimental model is applied to ABRs and sweep time is 2000

\begin{tabular}{|c|c|c|}
\hline $\begin{array}{c}\text { 加算2000回ABR } \\
\text { タイプ }\end{array}$ & AICの最小值 & $\begin{array}{c}\text { AICの最小值を } \\
\text { 与える次数 } \mathrm{n}\end{array}$ \\
\hline 1型 & $\mathbf{- 2 4 1 8 . 1 0}$ & 11 \\
\hline 2型 & $\mathbf{- 2 6 2 4 . 8 4}$ & 23 \\
\hline $3-1$ 型 & $\mathbf{- 2 6 9 6 . 2 4}$ & 18 \\
\hline 3-2型 & $\mathbf{- 2 4 4 2 . 6 9}$ & 22 \\
\hline
\end{tabular}

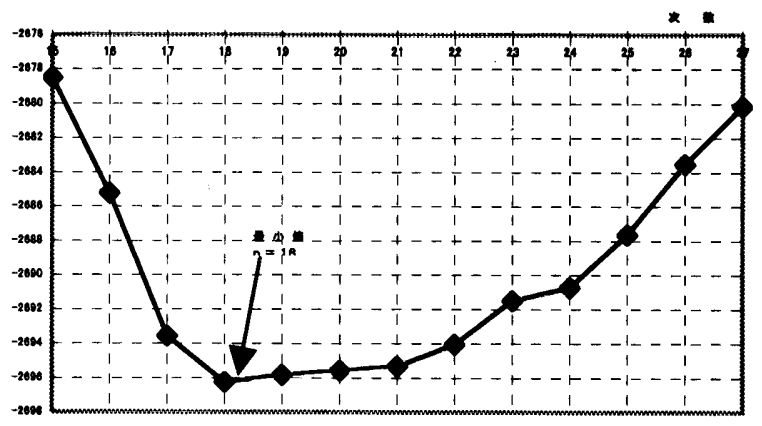

図 8 実験モデルを加算回数2000回のABR(3-1型) に適用した場合のAICと次数の関係（最小值付 近のみを表示)

Fig.8 Relationship between AIC value and degree when experimental model is applied to ABR (type3-1) and sweep time is 2000

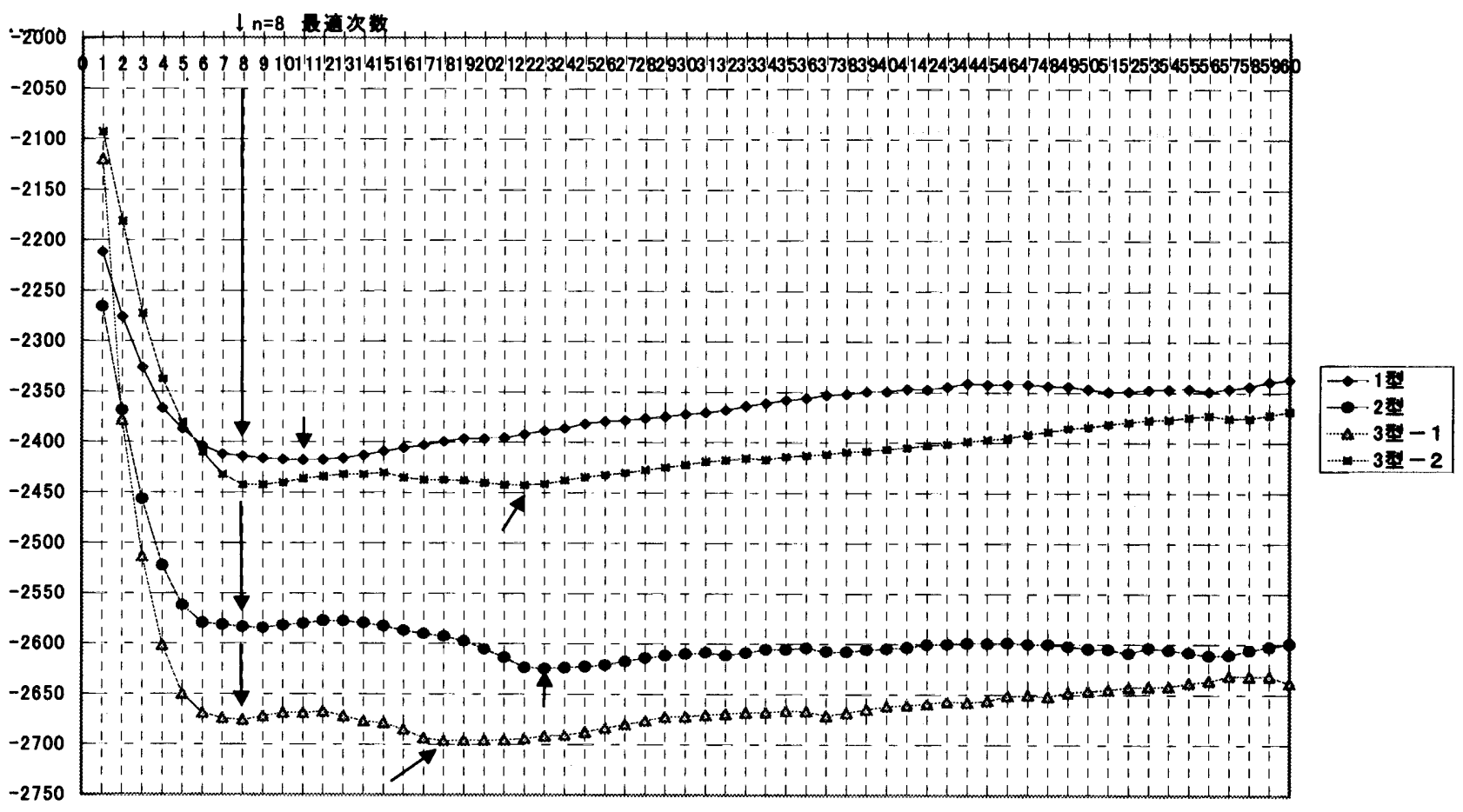

図 $9 \mathrm{ABR} 2000$ 回波形の 4つの型における AIC の最小值と次数の関係

Fig.9 Relationship between AIC value and degree when experimental model is applied to four types of $\mathrm{ABR}$ and sweep time is 2000 


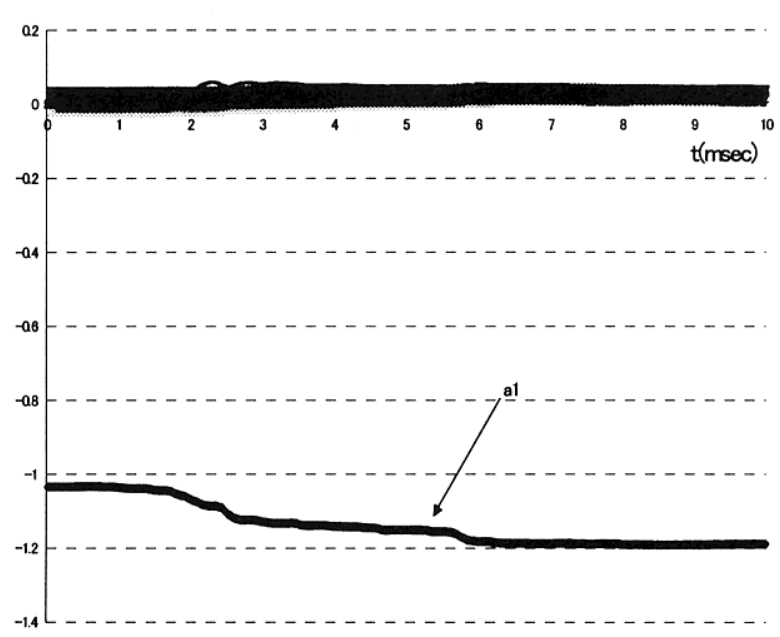

(a) 係数a

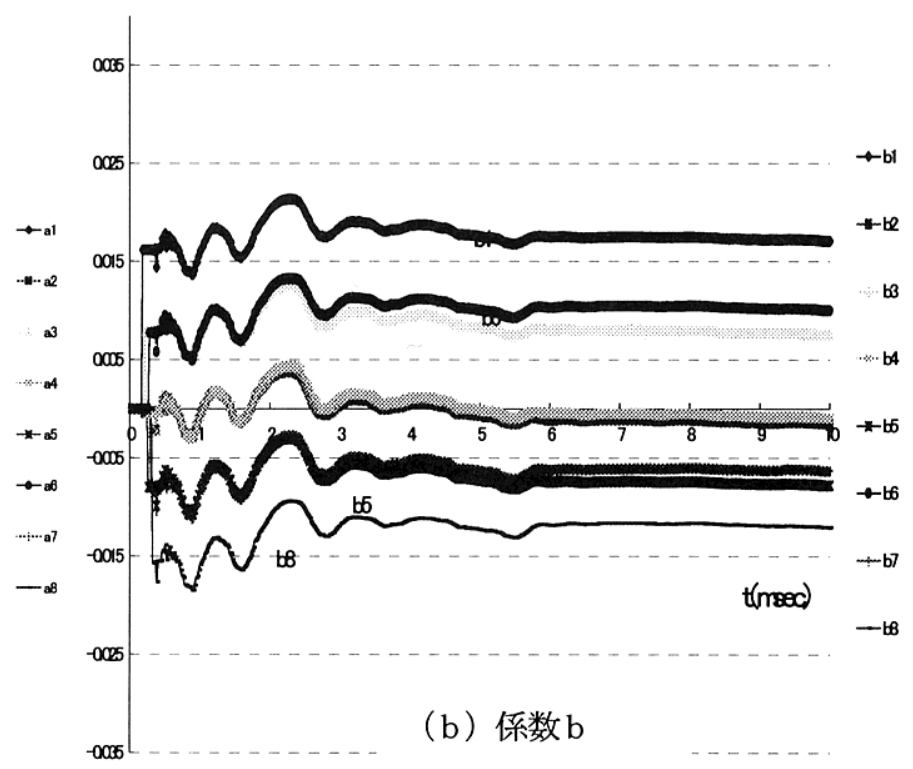

図 102000 回加算における（次数 8）の伝達関数係数の収束の様子

Fig.10 Results of coefficients of the ABR transfer function when sweep time is 2000 and model of degree 18 is used

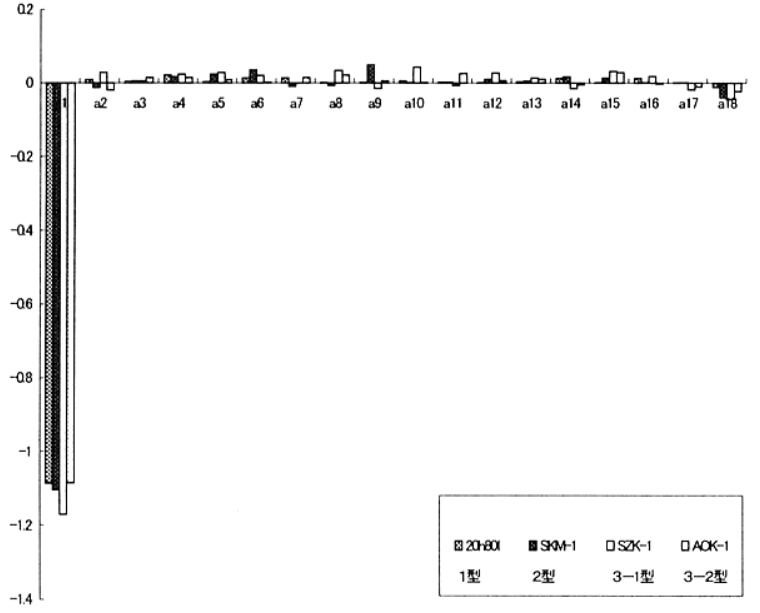

（a）次数 $=18$ の場合

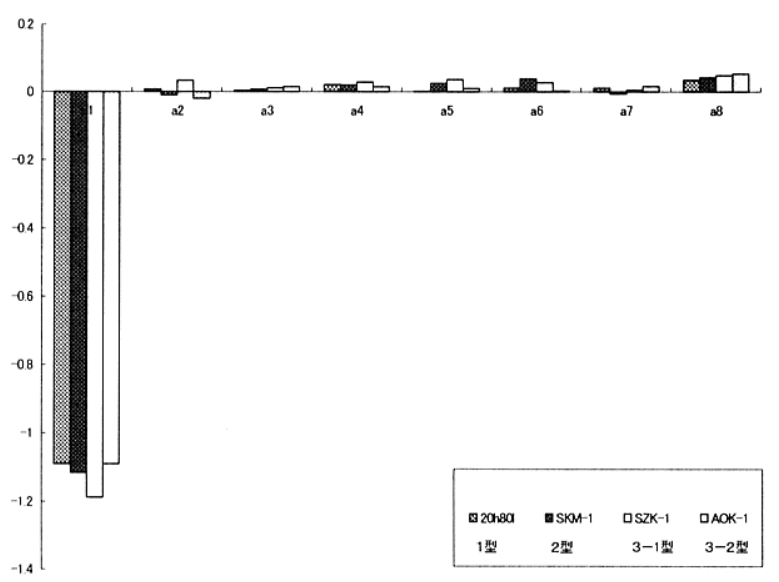

(b) 次数 $=8$ 場合

図11 2000回加算における4つの型のABR（最適次数と最小次数）の伝達関数係数の収束值の比較

Fig.11 Convergent results of coefficients of the all types of ABR transfer functions when sweep time is 2000 and models of degree 18 and 8 are used 

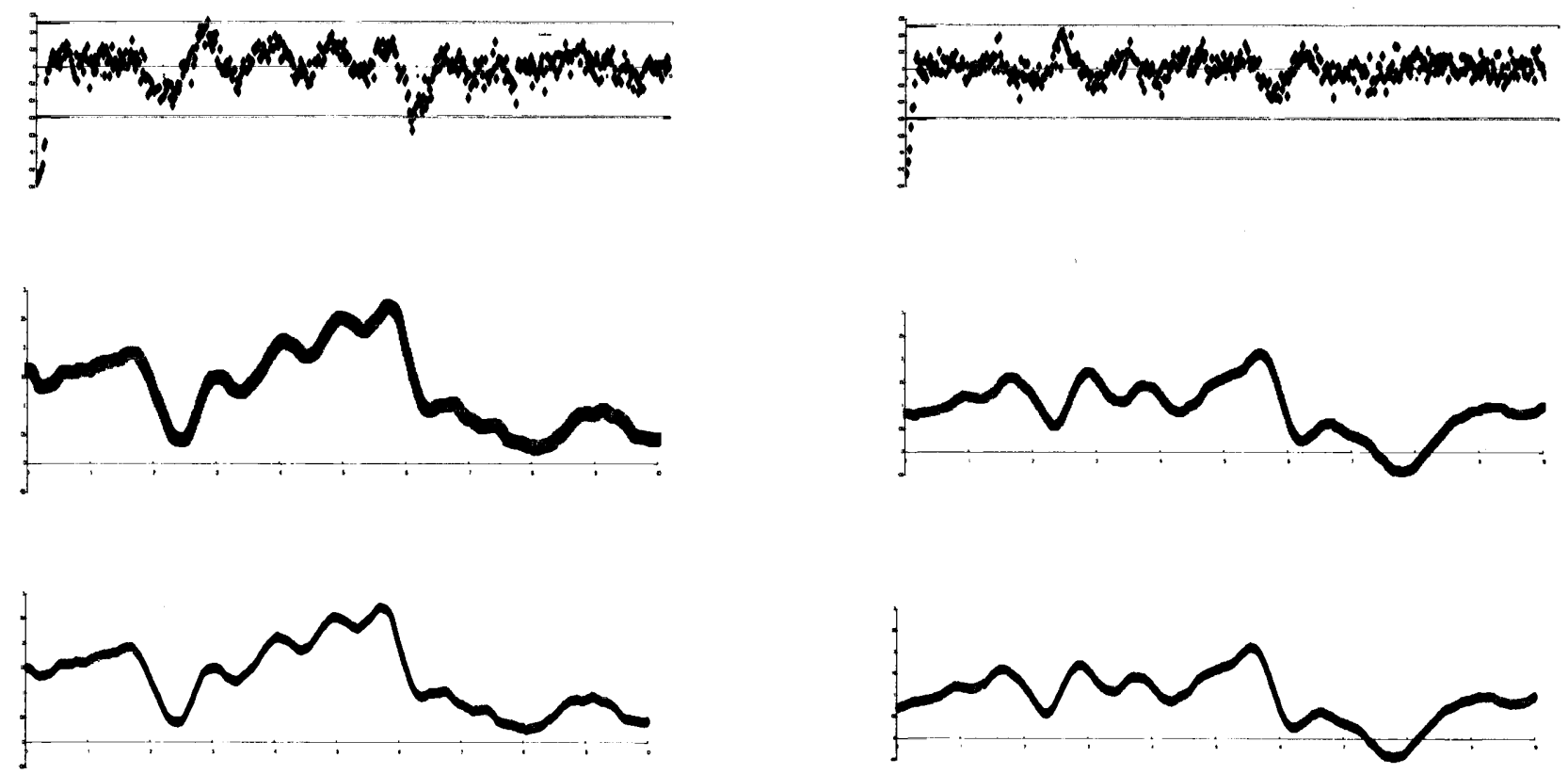

（a）タイプ1型の比較 上段は予測誤差系列 (標準偏差0.02), 中断は計算推定値, 下段は観測値

（c）タイプ3-1型の比較 上段は予測誤差系列 (標淮偏差0.02), 中断は計算推定値, 下段は観測值
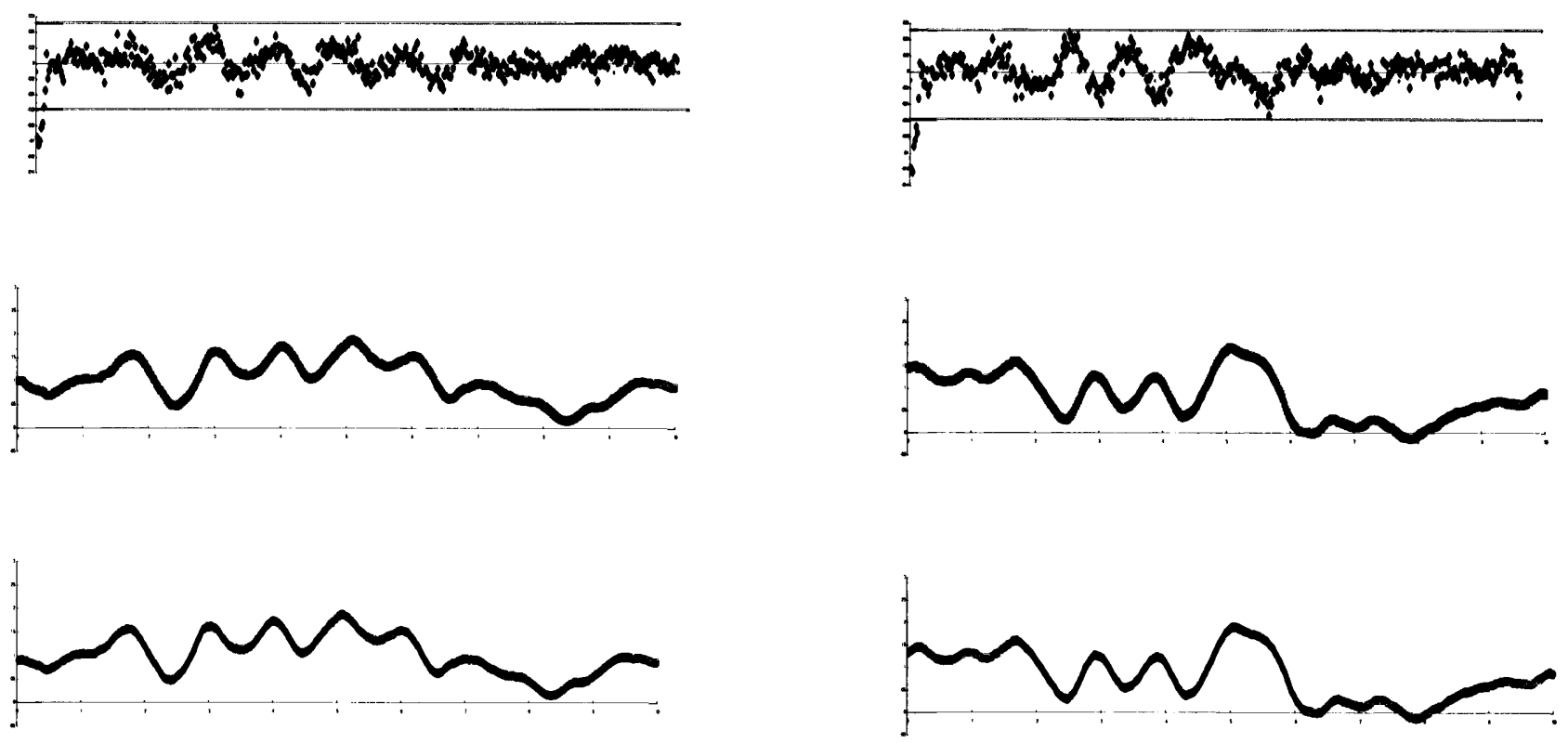

（b）タイプ 2 型の比較 上段は予測誤差系列 (標隻偏差 0.02), 中断は計算推定值，下段は観測值

(d) タイプ3-2型の比較 上段は予測誤差系列 (標淮偏差0.02), 中断は計算推定值, 下段は観測値

図12 4つの型（(a)〜 (d)）のABR2000回加算における観測值とカルマンフィルタモデル（次数8）による計算推定 值の比較および残差

Fig.12 Comparison between measured and calculated ABRs and the residue when sweep time is 2000 and model of degree 8 is used 

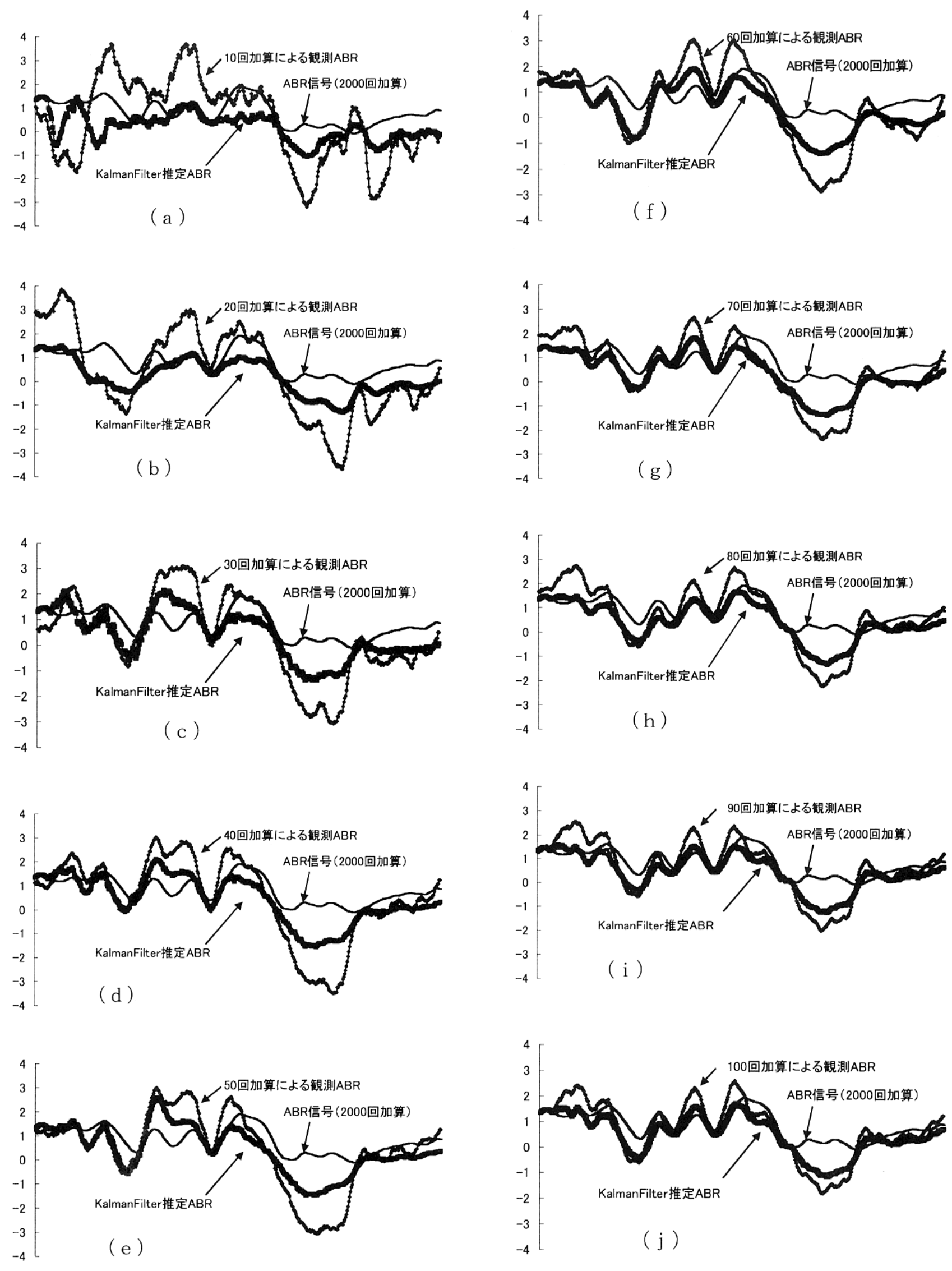

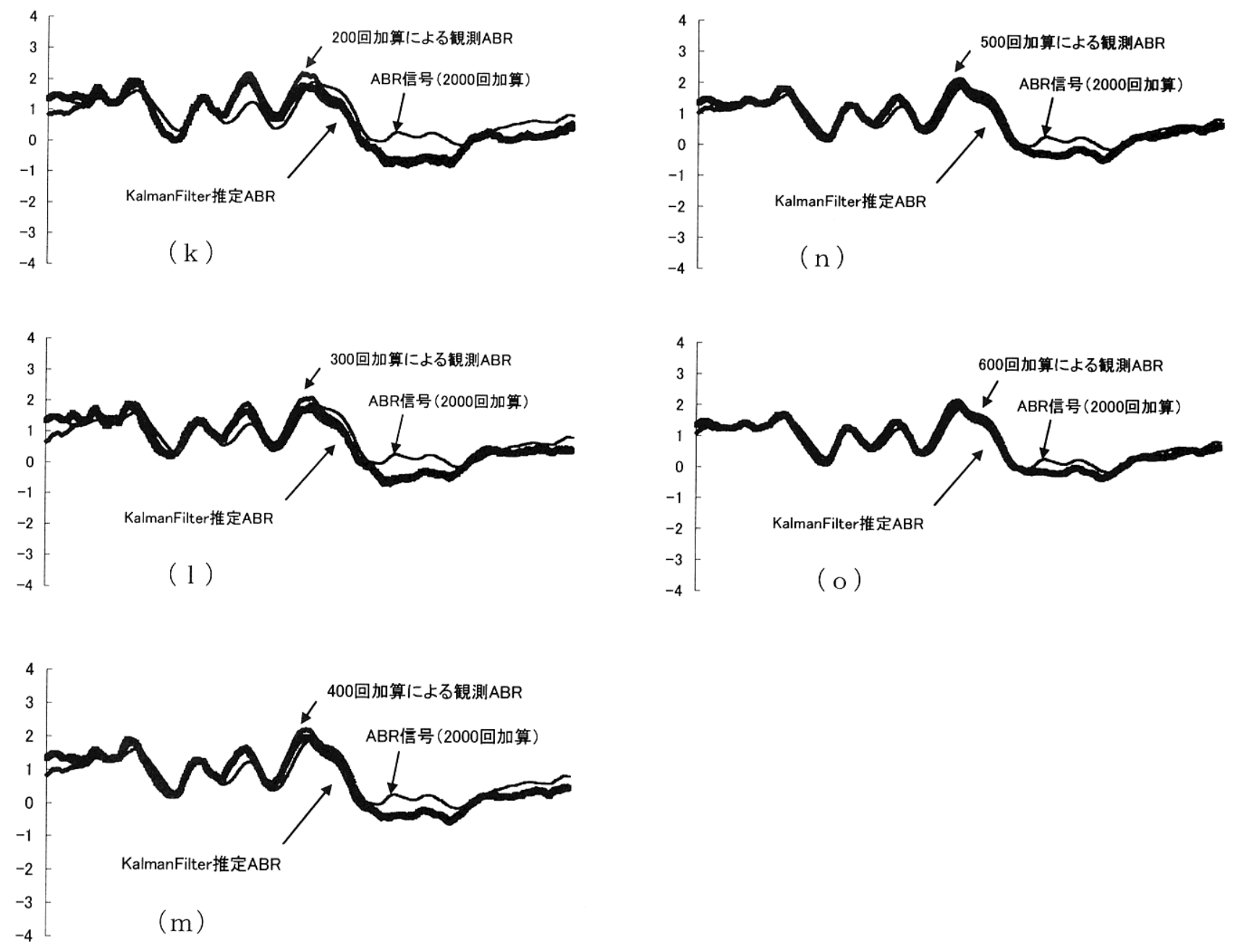

図13 タイプ3-2型ABR観測波形, 加算回数10-100 ( (a)-(j) 10ずつ増分), 100-600 ( (j)-(o) 100ずつ増分) 回におけるカ ルマンフィルタ推定值と観測值，目的波形 (2000回) の比較（次数8）

Fig.13 Results of coefficients of the ABR transfer functions when sweep time is ,10-100 ((a)-(j) : increment 10), $100-600(\mathrm{j})-(\mathrm{o}):$ increment 100$)$ and model of degree 8 is used

予測誤差系列の標準誤差 (SD, 4 型とも約 0.02$)$ の \pm SSD レベルを示す。立ち上がり $n<8$ を除いて, 4 つのタイプと もほぼ士3SD 内に収まっている。

\section{4. 少ない加算回数での観測波形からの信号 抽出}

3.2.3 では, 加算回数と ABR 実験観測波形の雑音成分に ついて述べ，また，3.5 では加算 2000 回を $\mathrm{ABR}$ の信号波 形として, その伝達関数の係数を求めた。本章では, 本研 究の目的である “より少ない加算における $\mathrm{ABR}$ 観測波形 の信号抽出”について考察する。そこで前節で求めた 2000 回加算の $\mathrm{ABR}$ 観測值を目的波形とする。そして, カルマ ンフィル夕による推定值の評価にこの目的波形を利用し,

Journal of Signal Processing, Vol. 8, No. 4, July 2004
また，推定における入力はそれぞれの加算回数の観測值を 用いる。カルマンフィルタによる推定によって, この少な い加算回数の観測波形に埋もれている信号成分の特徽を抽 出することが可能となる。またこの推定によって，単なる 加算平均より目的信号に相関度の高い推定值を得ることが できた。

\section{1 少ない加算回数の観測波形に対するカルマン フィルタを用いた推定}

図 2 に示した $\mathrm{ABR}$ 波形タイプ 3-2 型を例として, 推定 を実施した。2000 回加算した $\mathrm{ABR}$ 観測波形を推定におけ る推定目標值（目的信号）と寸る。2000 回以下，具体的に は 10 回から 10 ずつ刻んで 100 回までと 100 回から 100 ずつ刻んで 600 回まで平均加算した観測波形を実測值 (入 


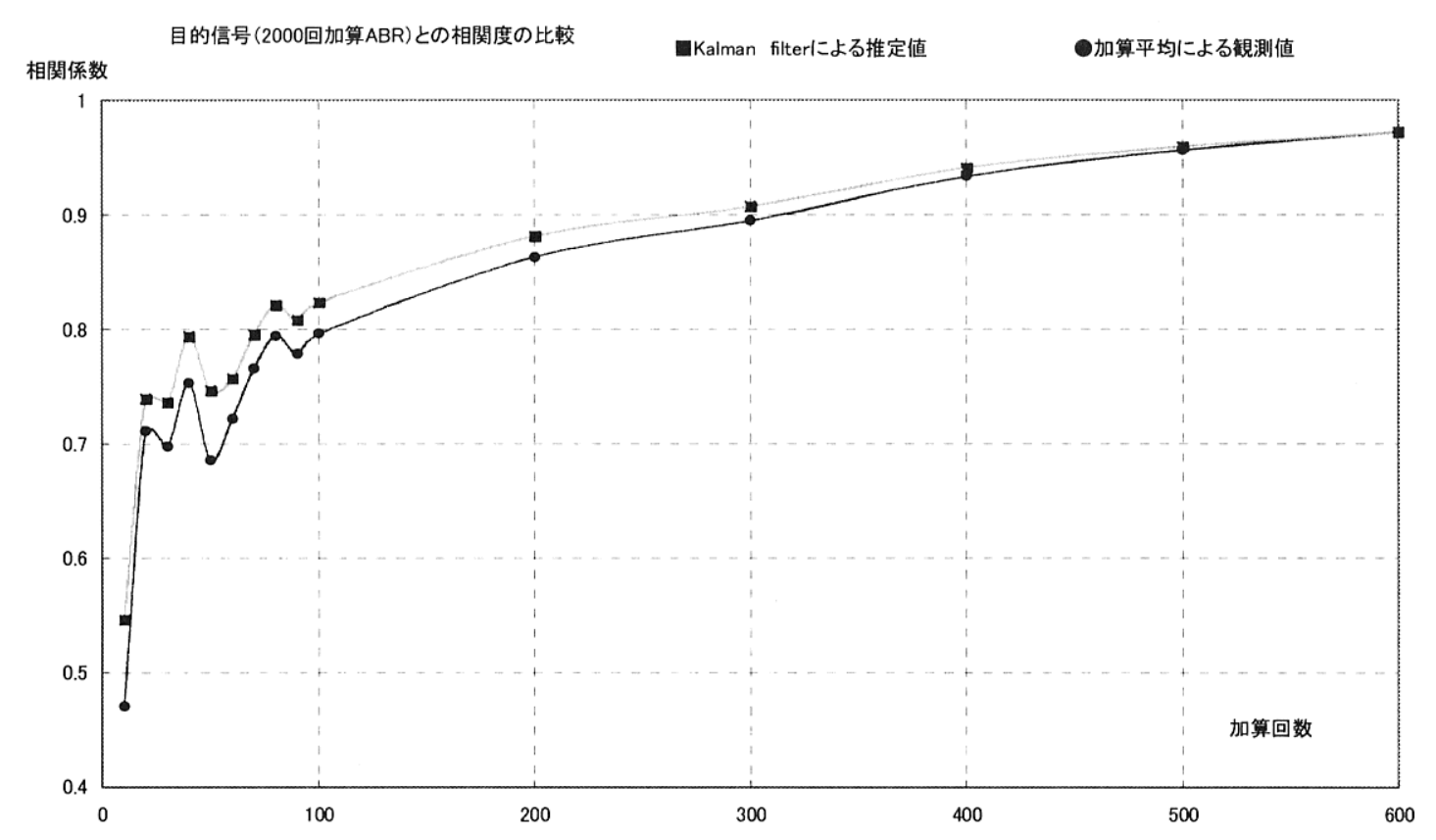

図14 カルマンフィルタ（次数8）による推定值と加算平均による実測值との相関度の比較

Fig.14 Comparison between measured and calculated ABRs and the residue when sweep time is 100 and model of degree 8 is used

カ）としてカルマンフィルタによる推定を実施する。図 13 にその結果を示す。この図では, (a)〜 (j)がそれぞれ 10 回 から 10 ずつ加算を増やした結果, (j)〜(o)が 100 回から 100 ずつ加算を増やした結果を示している。各グラフの点線は 従来の平均加算波形, 連続線は目的信号 $(2000$ 回加算して 得られる ABR 波形), 太線はカルマンフィルタによる推定 波形を示している。

\section{2 平均加算との相関度の比較}

図 13 に示した推定の有效性を評価するために，実測值 (従来の加算平均による波形) とカルマンフィルタによる 推定值の, 目的信号 (2000 回加算して得られる $\mathrm{ABR}$ 波形) に対寸る相関係数を求め, 図 14 に示す。この図加, ど の加算回数の場合についても, 従来の単なる加算平均より もカルマンフィルタによる推定波形の方が，より目的波形 に相関度が高いという結果を得ることがわかる。

\section{5. むすび}

AICとカルマンフィルタを適用した最小分散推定法を用 いて, ABR信号波形の伝達関数の次数およびパラメータを 推定することができた。本手法では逐次的にABRの伝墶関 数を特徽抽出することができるため従来 2000 回程度の平 均加算を経て得られていたABR信号を, より少ない加算回
数において抽出することを可能にしている。具体的にはま ずABR信号として, 目的波形の伝達関数の特徵を抽出し確 定している。そして，これを(目的) 信号波形とし，これ に対して, より少ない加算回数で得られた観測信号から力 ルマンフィルタ推定を用いてABR信号をオンラインで推 定寸るシステムを提案している。その際, カルマンフィル 夕による推定を用いることで比較的単純でかつ, ABR信号 に対して単なる加算平均より相関度の高い波形の特徴抽出 を可能にしている。このことは, 加算平均によるロスを軽 減しているといってよい。すなわち，この手法を計測シス テムに導入することで従来の計測システムより短い時間お よび高い精度でABR信号の抽出が期待され, ABR測定シス テムの改善において，大きな前進と考えている。

また, さらにこのシステムを, 疾患者など多種の $\mathrm{ABR}$ 信号波形に適用寸ることが可能であると考えている。それ によって, 健常者と脳死患者の観察波形を伝達特性から識 別することも実現可能であるといえる。オンライン推定を 実現するこのシステムを臨床面でより実用的にするために は, さらなる $\mathrm{ABR}$ 観測波形に対するこのシステムの検証 が必要である。

\section{参考文献}

[1] 鈴木篤郎監修: 聴性脳幹反応, メジカルビュー社, 1989.

[2] 加我君孝編 : ABRハンドブック, 金原出版, 1998. Journal of Signal Processing, Vol. 8, No. 4, July 2004 
［3］河村正三監修，市川銀一郎編集 : 初心者のための聴性誘発反 応アトラス, 廣川書店, 1988 .

[4] B. S. Herrmann : Inside the black box "How does the ALGO work anyway?", Clinical Series, No. 3 Natus Medical Inc., 1995.

[5] B. S. Herrmann, A. R. Thornton and J. M. Joseph : Automated infant hearing screening using the ABR: Development and validation, American Journal of Audiology, Vol.4, No. 2, pp. 6-14, 1995.

[6] 井川信子, 倉田 是 : クリック音刺激による聴性脳幹反応第 V波の自動判定システムの構築の試みとしての音刺激強度潜時曲線の数式化，流経法学, Vol. 1, No. 1, pp. 73-94, 2002.

[7] 鈴木良次, 佐藤俊輔, 池田研二, 吉川 昭編 : 生体信号, 二 ロナ社, 1989.

[8] 谷萩隆嗣 : ディジタル信号処理の理論 3, コロナ社, 1986.

[9] 谷萩隆嗣 :ディジタル信号処理と基礎理論, コロナ社, 1996.

[10] 井川信子, 加藤修一, 有賀正浩, 倉田 是: クリック音刺激 と聴性脳幹反応第 $\mathrm{V}$ 波ピーク潜時との関係式，日本音響学会 誌, Vol. 54, No. 9, pp.632-640, 1998.

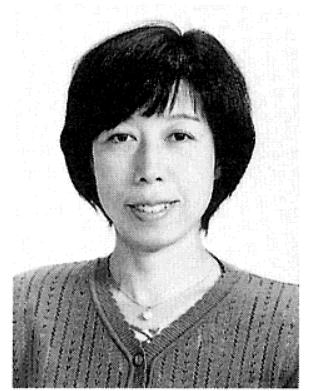

井川 信子 1979年東京女子大学文 理学部数理学科卒。1982年同大大学院 理学研究科数学専攻 (修士課程) 了。 理学修士。千葉大学大学院自然科学研 究科生産科学専攻 (博士課程) 単位取 得退学。産能大学経営情報学部助手, ソフトウェアジェネレーション商品開 発部勤務等を経て2001年より流通経済 大学法学部・助教授。生体情報システムのモデル化の研究, 特に 聴性脳幹反忘波形の推定と特徵抽出にかかわる信号処理, 推定理 論の研究に従事。電子情報通信学会, 日本音響学会, 神経回路学 会各会員。

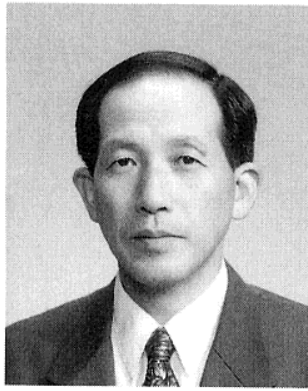

谷萩 隆嗣 1966年東工大・理工・ 電子卒。1971年同大大学院理工学研究 科電子工学専攻 (博士課程) 了。工博。 1971年千葉大・工・電子・講師, 1974 年同電子・助教授, 1984 年同電気・教 授, 1989年同情報・教授, 1998年同大 学院自然科学研究科・教授。ディジタ ルフィルタ, ディジタル画像処理, パターン認識, ディジタル音声信号処理, ディジタル通信, ディ ジタル制御, 適応ディジタル信号処理, ニューラルネットワーク, 数值解析, 推定理論など, 主として広義のディジタル信号処理の 研究に従事。IEEE Japan Chapter of Signal Processing Society 元会長。信号処理学会会長。Journal of Signal Processing 総編集 長。「ディジタル信号処理ライブラリー」（コロナ社）企画・編集 責任者。著書「ディジタル信号処理の理論, 第1巻〜第3巻」(コロ ナ社, 1985, 1985, 1986),「ディジタル信号処理の基礎理論」(コ ロナ社, 1996), 「音声と画像のディジタル信号処理 (共著)」(コ ロナ社, 1996), 「VLSIとディジタル信号処理 (共著)」(コロナ社, 1997),「マルチメディアとディジタル信号処理 (共著)」(コロナ 社, 1997)，「ニューラルネットワークとファジィ信号処理 (共著)」 （コロナ社, 1998), 「情報通信とディジタル信号処理 (共著)」(コ ロナ社，1999）、「高速アルゴリズムと並列信号処理（共著)」(コ ロナ社, 2000),「ディジタルフィルタと信号処理」(コロナ社, 2001）など。1988年電気通信普及財団賞（テレコムシステム技術 賞)，1997年日本印刷学会論文賞など受賞。IEEE，電子情報通信 学会, システム制御情報学会, 日本印刷学会各会員。

(2003年10月 1 日受付, 2004 年 1 月 23 日再受付) 